\title{
Synthesis and Inhibition Mechanism of Alac-Acetogenins, a Novel Type of Inhibitor of Bovine Heart Mitochondrial Complex $\mathrm{I}^{\dagger}$
}

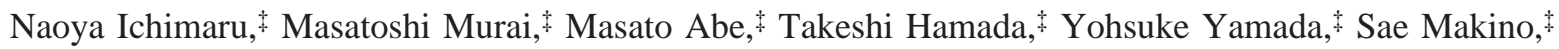 \\ Takaaki Nishioka, ${ }^{\ddagger}$ Hidefumi Makabe, ${ }^{\S}$ Asami Makino," Toshihide Kobayashi," and Hideto Miyoshi*,\$ \\ Division of Applied Life Sciences, Graduate School of Agriculture, Kyoto University, Sakyo-ku, Kyoto 606-8502, Japan, \\ Science of Functional Foods, Graduate School of Agriculture, Shinshu University, Kamiina, Nagano 399-4598, Japan, and \\ Supra-Biomolecular System Research Group, RIKEN (Institute of Physical and Chemical Research), Frontier Research System, \\ Wako-shi, Saitama 351-0198, Japan
}

Received September 27, 2004; Revised Manuscript Received October 31, 2004

\begin{abstract}
We have synthesized $\Delta$ lac-acetogenins that are new acetogenin mimics possessing two $n$-alkyl tails without an $\alpha, \beta$-unsaturated $\gamma$-lactone ring and suggested that their inhibition mechanism may be different from that of common acetogenins [Hamada et al. (2004) Biochemistry 43, 3651-3658]. To elucidate the inhibition mechanism of $\Delta$ lac-acetogenins in more detail, we carried out wide structural modifications of original $\Delta$ lac-acetogenins and characterized the inhibitory action with bovine heart mitochondrial complex I. In contrast to common acetogenins, both the presence of adjacent bis-THF rings and the stereochemistry around the hydroxylated bis-THF rings are important structural factors required for potent inhibition. The inhibitory potency of a derivative possessing an $n$-butylphenyl ether structure (compound 7) appeared to be superior to that of the original $\Delta$ lac-acetogenins and equivalent to that of bullatacin, one of the most potent natural acetogenins. Double-inhibitor titration of steady-state complex I activity showed that the extent of inhibition of compound $\mathbf{7}$ and bullatacin is not additive, suggesting that the binding sites of the two inhibitors are not identical. Competition tests using a fluorescent ligand indicated that the binding site of compound 7 does not overlap with that of other complex I inhibitors. The effects of compound 7 on superoxide production from complex I are also different from those of other complex I inhibitors. Our results clearly demonstrate that $\Delta$ lac-acetogenins are a novel type of inhibitor acting at the terminal electron-transfer step of bovine complex I.
\end{abstract}

Acetogenins isolated from the plant family Uvaria accuminata (Annonaceae) have very potent and diverse biological effects such as antitumor, antimalarial, pesticidal, and antifeedant activities $(1-3)$. The inhibitory effect of acetogenins on mitochondrial NADH-ubiquinone oxidoreductase (complex I) ${ }^{1}$ is of particular importance since their diverse biological activities are thought to be attributable to this effect (3). Some acetogenins, such as bullatacin (Figure 1) and rolliniastatin 1 , are the most potent inhibitors of bovine heart mitochondrial complex I identified to date (4-7). Although acetogenins are thought to act at the terminal electron-transfer step of complex I $(6,7)$, there is still no hard experimental evidence to verify whether the inhibitors in fact bind to the ubiquinone reduction site. Additionally, there are few structural similarities between acetogenins and

$\dagger$ This work was supported in part by Grant-in-Aid for Scientific Research from the Japan Society for the Promotion of Science (Grant 15380083 to H.M.).

* To whom correspondence should be addressed. E-mail: miyoshi@ kais.kyoto-u.ac.jp. Tel: +81-75-753-6119. Fax: +81-75-753-6408.

Kyoto University.

$\S$ Shinshu University.

" RIKEN, Frontier Research System.

${ }^{1}$ Abbreviations: AQ, 6-amino-4-(4-tert-butylphenethylamino)quinazoline; complex I, mitochondrial proton-pumping NADHubiquinone oxidoreductase; DET, diethyl tartrate; DMAP, 4-(dimethylamino)pyridine; $\mathrm{Q}_{1}$, ubiquinone 1; SMP, submitochondrial particles; TBAF, tetra- $n$-butylammonium fluoride; THF, tetrahydrofuran. ordinary complex I inhibitors such as piericidin A, rotenone, and several synthetic agrochemicals represented by fenpyroximate. Thus, considering the unusual structural characteristics as well as the very strong inhibitory effect of acetogenins, a detailed analysis of the inhibitory action of these inhibitors may provide insights into the terminal electron-transfer step of complex I.

In the course of the structural modification of natural acetogenins, we have synthesized new acetogenin mimics that possess two alkyl tails without an $\alpha, \beta$-unsaturated $\gamma$-lactone ring, named $\Delta$ lac-acetogenins (8). The structural features of $\Delta$ lac-acetogenins are highly unique compared to those of ordinary complex I inhibitors and rather resemble amphiphilic phospholipid or detergent molecules. Interestingly, the $\Delta$ lac-acetogenin carrying two $n$-undecanyl groups (compound $\mathbf{1}$ in Figure 1) elicited very potent inhibition with bovine heart mitochondrial complex I despite the lack of an $\alpha, \beta$-unsaturated $\gamma$-lactone ring, which is one of the common structural features of a large number of natural acetogenins $(1-3)$. Double-inhibitor titration of steady-state complex I activity showed that the inhibition of compound $\mathbf{1}$ and bullatacin is not additive, suggesting that the binding sites of the two inhibitors are not identical (8). However, an electron paramagnetic resonance (EPR) spectroscopic study on the redox state of iron-sulfur clusters indicated that the inhibition site of compound $\mathbf{1}$ is downstream of the iron- 

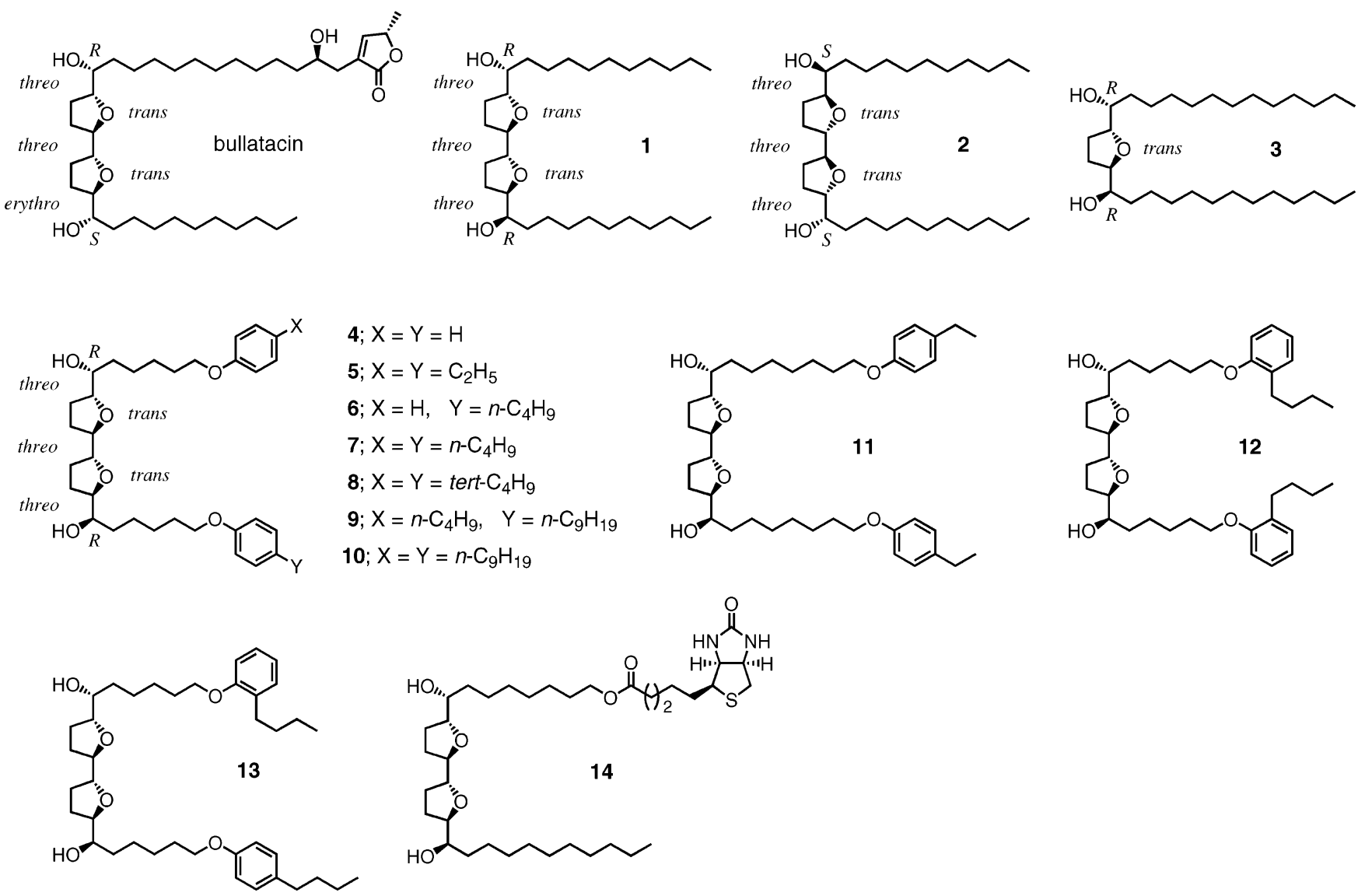

FIGURE 1: Structures of $\Delta$ lac-acetogenins synthesized in this study.

sulfur cluster N2, as is the case for other ordinary complex I inhibitors (8). These results along with somewhat different profiles of structure-activity relationship between $\Delta$ lacacetogenins and common acetogenins suggested that the mode of inhibitory action of $\Delta$ lac-acetogenins may be different from that of common acetogenins. Thus, as $\Delta$ lacacetogenins might be regarded as a novel type of inhibitor, detailed studies on the inhibitory action of these unique inhibitors will be helpful to elucidate the structural and functional features of the terminal electron-transfer step of the enzyme.

To fully understand the inhibitory action of $\Delta$ lac-acetogenins, some important questions remained to be answered: for instance, (i) from the viewpoint of the structure-activity relationship, whether the stereochemistry around the hydroxylated THF ring moiety as well as the presence of adjacent bis-THF rings is important for the inhibition (although these structural factors are not essential for common acetogenins; see refs 9-13); (ii) from the viewpoint of the inhibition mechanism, whether $\Delta$ lac-acetogenins share a common binding domain with other ordinary complex I inhibitors; and (iii) from the viewpoint of the design synthesis of molecular probes, whether one can develop new $\Delta$ lacacetogenins by replacing the straight alkyl tails with other structural modules while maintaining potent activity. In the present study, to answer these questions and also to further characterize the inhibitory action of $\Delta$ lac-acetogenins, we carried out structural modifications of the original $\Delta$ lacacetogenins and, consequently, obtained a very potent derivative (compound 7) superior to compound 1. Through characterization of the inhibitory action of compound 7 , we clearly demonstrated that $\Delta$ lac-acetogenins are a novel type of inhibitor of bovine mitochondrial complex I.

\section{EXPERIMENTAL PROCEDURES}

Synthetic Procedures. (A) Compound 2. The synthetic procedures of compound 2 are outlined in Scheme 1A. The intermediate $\mathbf{1 5}$ is an enantiomer of compound 19, which is a key intermediate used for the synthesis of the other derivatives. The six stereogenic centers in compound 19 were constructed by sequential double Sharpless asymmetric epoxidation and dihydroxylation (AD) using (+)-diethyl tartrate (DET) and $\mathrm{AD}-\mathrm{mix}-\beta$, respectively, as described previously (10). Therefore, using (-)-DET and AD-mix- $\alpha$ in place of (+)-DET and AD-mix- $\beta$, respectively, 15 was synthesized.

Then, to a mixture of $\mathbf{1 5}$ (100 mg, $0.2 \mathrm{mmol})$, DMAP (17 $\mathrm{mg}, 0.14 \mathrm{mmol})$, and $\mathrm{Et}_{3} \mathrm{~N}(1.5 \mathrm{~mL})$ in $\mathrm{CH}_{2} \mathrm{Cl}_{2}(3 \mathrm{~mL})$ was added $\mathrm{TsCl}$ (95 $\mathrm{mg}, 0.5 \mathrm{mmol})$ at room temperature. The reaction mixture was stirred at $30^{\circ} \mathrm{C}$ for $24 \mathrm{~h}$, then quenched, washed with brine, dried, and concentrated. The residue was purified by silica gel column chromatography (hexaneEtOAc, 1:1) to give the ditosyl derivative (153 mg, 96\%). To a solution of the product $(153 \mathrm{mg}, 0.192 \mathrm{mmol})$ in dry THF (15 mL) was added TBAF (1.0 M in THF, $0.4 \mathrm{~mL}, 0.4$ $\mathrm{mmol})$ at room temperature, and the mixture was stirred at $40{ }^{\circ} \mathrm{C}$ for $2 \mathrm{~h}$. The reaction mixture was quenched with saturated aqueous $\mathrm{NH}_{4} \mathrm{Cl}$, washed with brine, dried, and concentrated. The crude product was purified by silica gel column chromatography (hexane-EtOAc, 3:7) to afford diepoxide 16 (37.6 mg, 87\%). 
Scheme $1^{a}$

A)

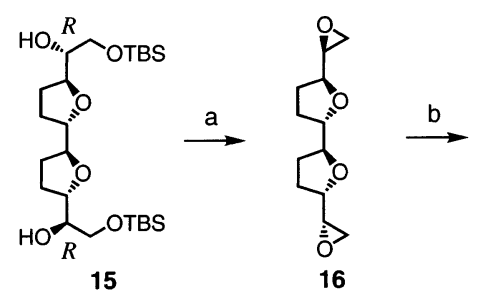

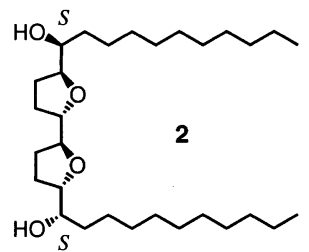

B)
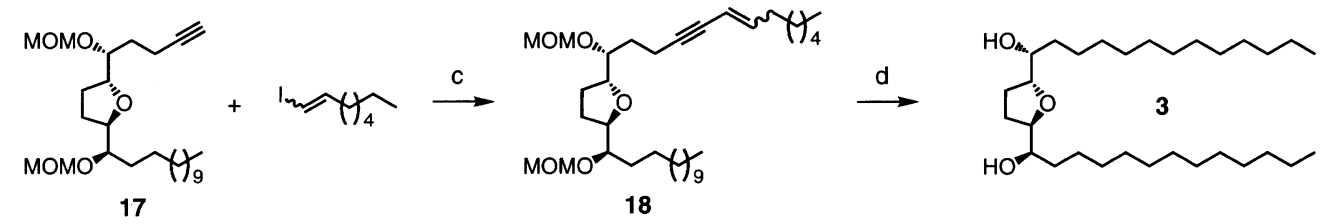

C)

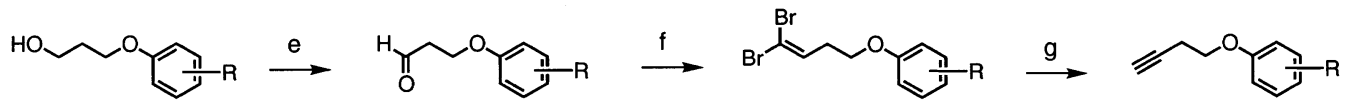

D)
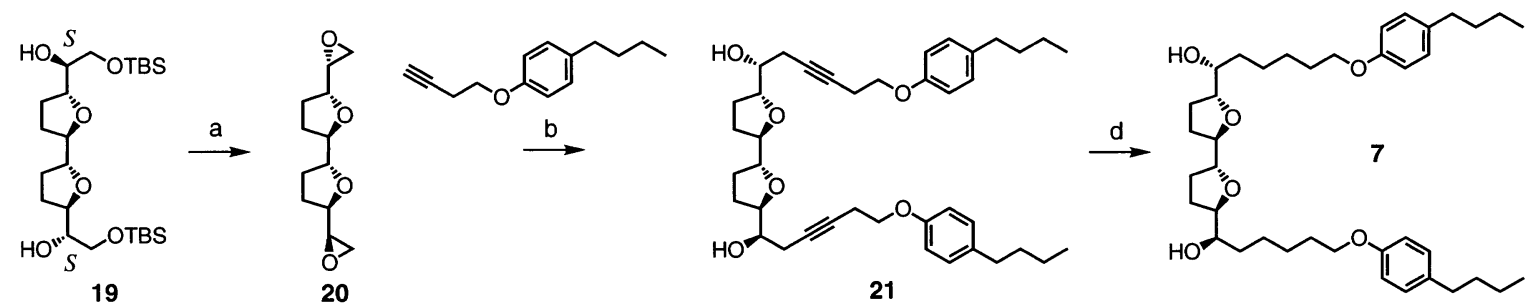

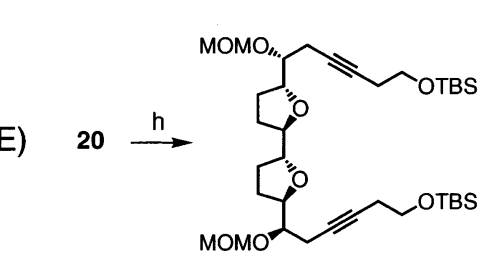

22

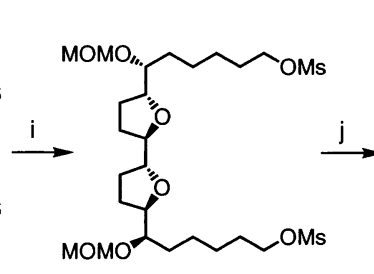

23

21

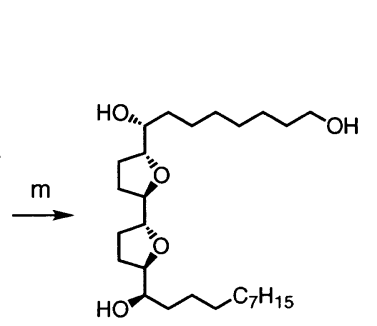

27

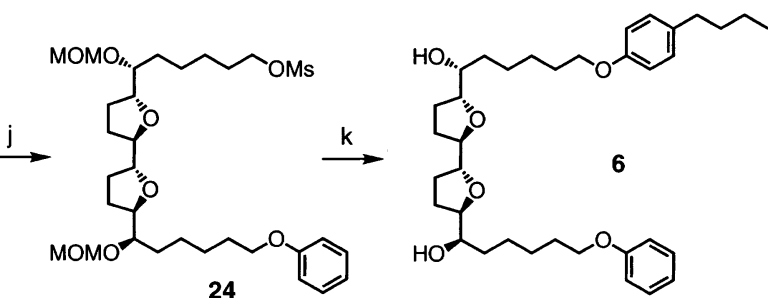

F)

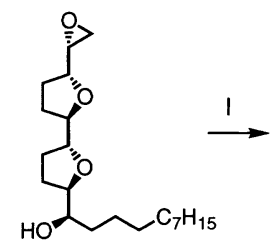

25

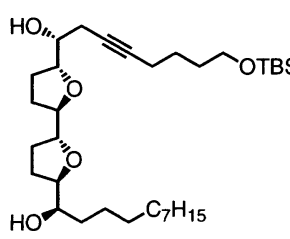

26

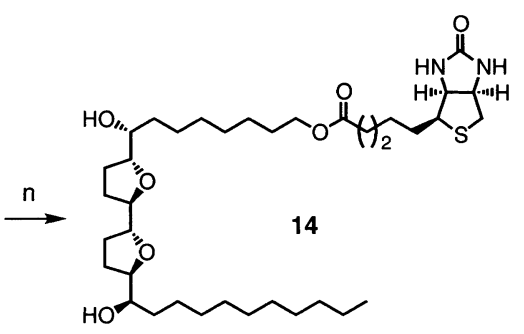

${ }^{a}$ Reaction conditions: (a) (i) $\mathrm{TsCl}, \mathrm{DMAP}, \mathrm{Et}_{3} \mathrm{~N}, \mathrm{CH}_{2} \mathrm{Cl}_{2}, 30{ }^{\circ} \mathrm{C}, 24 \mathrm{~h}, 96 \%$; (ii) TBAF (2.5 equiv), THF, $40{ }^{\circ} \mathrm{C}, 2 \mathrm{~h}, 87 \%$; (b) (i) 1 -nonyne,

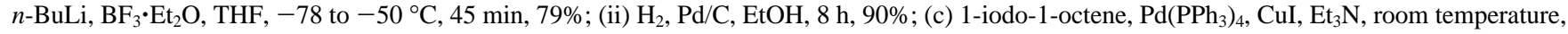
2.5 h, $80 \%$; (d) $\mathrm{H}_{2}, \mathrm{Pd} / \mathrm{C}$, EtOH, 8 h, $98 \%$; (e) Dess-Martin periodinane, $\mathrm{CH}_{2} \mathrm{Cl}_{2}, 0{ }^{\circ} \mathrm{C}, 1 \mathrm{~h}, 90-95 \%$; (f) $\mathrm{CBr}_{4}, \mathrm{Ph}_{3} \mathrm{P}, \mathrm{CH}_{2} \mathrm{Cl}_{2}$, room temperature, $0.5 \mathrm{~h}, 95-98 \%$; (g) $n$-BuLi (2 equiv), THF, -78 to $0{ }^{\circ} \mathrm{C}, 1 \mathrm{~h}, 93-98 \%$; (h) (i) 1 -(tert-butyldimethylsilyloxy)-3-butyne, $n$-BuLi, $\mathrm{BF}_{3} \cdot \mathrm{Et}_{2} \mathrm{O},-78$ to $-10{ }^{\circ} \mathrm{C}, 50 \mathrm{~min}, 82 \%$; (ii) chlorodimethyl ether, $(i-\mathrm{Pr})_{2} \mathrm{NEt}, \mathrm{CH}_{2} \mathrm{Cl}_{2}$, room temperature, $10 \mathrm{~h}, 97 \%$; (i) (i) $\mathrm{H}_{2}, \mathrm{Pd} / \mathrm{C}, \mathrm{EtOH}, 8 \mathrm{~h}, 91 \%$, (ii) $\mathrm{TBAF}(6$ equiv), THF, room temperature, $2 \mathrm{~h}, 99 \%$; (iii) $\mathrm{MsCl}, \mathrm{Et}_{3} \mathrm{~N}, \mathrm{THF}, 0{ }^{\circ} \mathrm{C}, 1 \mathrm{~h}, 95 \%$; (j) sodium phenoxide (1.2 equiv), acetone, $60{ }^{\circ} \mathrm{C}, 4 \mathrm{~h}, 37 \%$; (k) (i) sodium 4- $n$-butylphenoxide ( 2.5 equiv), acetone, $60{ }^{\circ} \mathrm{C}, 5 \mathrm{~h}, 85 \%$; (ii) $4 \% \mathrm{AcCl}$ in $\mathrm{MeOH}, \mathrm{CH}_{2} \mathrm{Cl}_{2}$, room temperature, $1 \mathrm{~h}, 96 \%$; (l) 6 -(tertbutyldimethylsilyloxy)-1-hexyne, $n$-BuLi, $\mathrm{Et}_{2} \mathrm{AlCl}, 0{ }^{\circ} \mathrm{C}, 1.5 \mathrm{~h}, 52 \%$; (m) (i) $\mathrm{H}_{2}, \mathrm{Pd} / \mathrm{C}, \mathrm{EtOH}, 8 \mathrm{~h}$; (ii) TBAF (2.5 equiv), THF, room temperature, 1.5 h, $91 \%$; (n) D-(+)-biotin, EDC, DMAP, $\mathrm{CH}_{2} \mathrm{Cl}_{2}$, room temperature, 4 days, $66 \%$.

To a solution of 1-nonyne $(270 \mathrm{mg}, 2.2 \mathrm{mmol})$ in dry THF $(1.5 \mathrm{~mL})$ at $-78^{\circ} \mathrm{C}$ was added a solution of $n-\mathrm{BuLi}(1.6 \mathrm{M}$ in hexane, $1.3 \mathrm{~mL}, 2.1 \mathrm{mmol})$. After $30 \mathrm{~min}, \mathrm{BF}_{3} \cdot \mathrm{Et}_{2} \mathrm{O}(0.2$ $\mathrm{mL}, 1.6 \mathrm{mmol}$ ) was added, and the mixture was stirred for $15 \mathrm{~min}$. To the mixture was added a solution of $\mathbf{1 7}$ (100 $\mathrm{mg}, 0.44 \mathrm{mmol})$ in THF $(1.8 \mathrm{~mL})$, and the resultant mixture was stirred for $45 \mathrm{~min}$ at -78 to $-50{ }^{\circ} \mathrm{C}$. The reaction mixture was worked up with saturated aqueous $\mathrm{NH}_{4} \mathrm{Cl}$, washed with brine, dried, and concentrated. The residue was purified by silica gel column chromatography (hexaneEtOAc, 3:7) to give the diol derivative (165 mg, 79\%). A mixture of the product $(165 \mathrm{mg}, 0.35 \mathrm{mmol})$ and $10 \% \mathrm{Pd} / \mathrm{C}$ $\left(10 \mathrm{mg}\right.$ ) in ethanol (4 mL) was stirred under a $\mathrm{H}_{2}$ atmosphere at room temperature for $8 \mathrm{~h}$. The crude product was purified 
by silica gel column chromatography (hexane-EtOAc, 1:1) to afford $2(149 \mathrm{mg}, 90 \%)$ as a colorless oil. The ${ }^{1} \mathrm{H}$ and ${ }^{13} \mathrm{C}$ NMR data of $\mathbf{2}$ were identical to those of $\mathbf{1}(8)$, but with the opposite optical rotation, $[\alpha]^{26}{ }_{\mathrm{D}}-9.2\left(c 0.35, \mathrm{CHCl}_{3}\right) .{ }^{1} \mathrm{H}$ NMR $\left(500 \mathrm{MHz}, \mathrm{CDCl}_{3}\right) \delta 3.88-3.84(\mathrm{~m}, 4 \mathrm{H}), 3.38(\mathrm{~m}$, $2 \mathrm{H}), 2.44$ (br s, 2H), $1.96(\mathrm{~m}, 4 \mathrm{H}), 1.69-1.63(\mathrm{~m}, 4 \mathrm{H}), 1.43-$ $1.25(\mathrm{~m}, 36 \mathrm{H}), 0.87(\mathrm{t}, J=6.9 \mathrm{~Hz}, 6 \mathrm{H}) .{ }^{13} \mathrm{C}$ NMR $(125$ $\left.\mathrm{MHz}, \mathrm{CDCl}_{3}\right) \delta 83.14,81.78,74.06,33.47,31.91,29.74$, 29.63, 29.34, 28.98, 25.66, 22.69, 14.13. ESI-MS $(\mathrm{m} / z) 505.5$ $[\mathrm{M}+\mathrm{Na}]^{+}$.

(B) Compound 3. The synthetic procedures of compound $\mathbf{3}$ are outlined in Scheme 1B. To a stirred solution of $\mathbf{1 7}$ (10 $\mathrm{mg}, 0.02 \mathrm{mmol}$ ), which is the same sample as that synthesized previously (12), and 1-iodo-1-octene (13 mg, 0.055 mmol) in $\mathrm{Et}_{3} \mathrm{~N}(1 \mathrm{~mL})$ were added $\mathrm{Pd}\left(\mathrm{PPh}_{3}\right)_{4}(2.8 \mathrm{mg}, 2.5$ $\mu \mathrm{mol})$ and $\mathrm{CuI}(1.4 \mathrm{mg}, 7.5 \mu \mathrm{mol})$ at room temperature, and the reaction mixture was stirred at room temperature for 2.5 $h$. The reaction was quenched by the addition of water, and the resulting mixture was extracted with EtOAc. The extract was washed with saturated aqueous $\mathrm{Na}_{2} \mathrm{~S}_{2} \mathrm{O}_{3}$, followed by water, dried, and concentrated. The crude product was purified by silica gel column chromatography (hexaneEtOAc, 4:1) to afford $\mathbf{1 8}(10 \mathrm{mg}, 80 \%)$. A mixture of $\mathbf{1 8}$ $(10 \mathrm{mg}, 16 \mu \mathrm{mol})$ and $10 \% \mathrm{Pd} / \mathrm{C}(5 \mathrm{mg})$ in ethanol $(2 \mathrm{~mL})$ was stirred under a $\mathrm{H}_{2}$ atmosphere at room temperature for $8 \mathrm{~h}$. The crude product was purified by silica gel column chromatography (hexane-EtOAc, 4:1) to afford 3 (10 mg, 98\%) as a colorless oil. ${ }^{1} \mathrm{H}$ NMR $\left(300 \mathrm{MHz}, \mathrm{CDCl}_{3}\right) \delta 3.81$ (m, 2H), 3.40 (m, 2H), 2.31 (br s, 2H), 2.03-1.94 (m, 2H), $1.71-1.66(\mathrm{~m}, 2 \mathrm{H}), 1.49-1.25(\mathrm{~m}, 44 \mathrm{H}), 0.87(\mathrm{t}, J=6.9$ $\mathrm{Hz}, 6 \mathrm{H}) .{ }^{13} \mathrm{C}$ NMR $\left(70 \mathrm{MHz}, \mathrm{CDCl}_{3}\right) \delta 82.62,74.03,33.50$, $31.92,29.65,29.36,28.73,25.61,22.69,14.12$. ESI-MS $(\mathrm{m} /$ z) $491.5[\mathrm{M}+\mathrm{Na}]^{+}$.

(C) Compounds 4, 5, 7, 8, 10, 11, and 12. The synthetic procedures of these compounds are described taking compound 7 as an example (Scheme 1D). To a solution of 4-(4n-butylphenoxy)-1-butyne (133 mg, $0.67 \mathrm{mmol}$ ), which was prepared by the method outlined in Scheme 1C, in dry THF $(3 \mathrm{~mL})$ at $-78{ }^{\circ} \mathrm{C}$ was added a solution of $n-\mathrm{BuLi}(1.6 \mathrm{M}$ in hexane, $0.4 \mathrm{~mL}, 0.64 \mathrm{mmol})$. After $30 \mathrm{~min}, \mathrm{BF}_{3} \cdot \mathrm{Et}_{2} \mathrm{O}(60$ $\mu \mathrm{L}, 0.48 \mathrm{mmol}$ ) was added, and the mixture was stirred for $20 \mathrm{~min}$. To the mixture was added a solution of $\mathbf{2 0}(30 \mathrm{mg}$, $0.13 \mathrm{mmol})$ in THF $(1.8 \mathrm{~mL})$, and the resultant mixture was stirred for $50 \mathrm{~min}$ at -78 to $-10{ }^{\circ} \mathrm{C}$. The reaction mixture was worked up with saturated aqueous $\mathrm{NH}_{4} \mathrm{Cl}$, washed with brine, dried, and concentrated. The residue was purified by silica gel column chromatography (hexane-EtOAc, 3:7) to give 21 (76 mg, 91\%). A mixture of 21 (76 mg, $0.12 \mathrm{mmol}$ ) and $10 \% \mathrm{Pd} / \mathrm{C}(5 \mathrm{mg})$ in ethanol $(4 \mathrm{~mL})$ was stirred under a $\mathrm{H}_{2}$ atmosphere at room temperature for $8 \mathrm{~h}$. The crude product was purified by silica gel column chromatography (hexane-EtOAc, 1:1) to afford 7 (70 $\mathrm{mg}, 91 \%)$ as a colorless oil. ${ }^{1} \mathrm{H}$ NMR $\left(300 \mathrm{MHz}, \mathrm{CDCl}_{3}\right) \delta 7.07(\mathrm{~d}, J=8.6 \mathrm{~Hz}$, $4 \mathrm{H}), 6.80(\mathrm{~d}, J=8.6 \mathrm{~Hz}, 4 \mathrm{H}), 3.92(\mathrm{t}, J=6.5 \mathrm{~Hz}, 4 \mathrm{H})$, $3.87-3.82(\mathrm{~m}, 4 \mathrm{H}), 3.39(\mathrm{~m}, 2 \mathrm{H}), 2.53(\mathrm{t}, J=7.6 \mathrm{~Hz}, 4 \mathrm{H})$, 2.45 (br s, 2H), 1.99-1.96 (m, 4H), 1.80-1.75 (m, 4H), $1.69-1.34(\mathrm{~m}, 24 \mathrm{H}), 0.91(\mathrm{t}, J=7.3 \mathrm{~Hz}, 6 \mathrm{H}) .{ }^{13} \mathrm{C} \mathrm{NMR}$ $\left(100 \mathrm{MHz}, \mathrm{CDCl}_{3}\right) \delta 157.09,134.83,129.20,114.24,83.14$, $81.79,73.96,67.85,34.73,33.92,33.36,29.31,28.98,28.35$, 26.15, 25.43, 22.31, 13.97. ESI-MS $(\mathrm{m} / \mathrm{z}) 661.6[\mathrm{M}+\mathrm{Na}]^{+}$.

Compounds $4,5,8,10,11$, and 12 were synthesized by the same procedures using the corresponding alkynes.
Compound 4: ${ }^{1} \mathrm{H}$ NMR $\left(300 \mathrm{MHz}, \mathrm{CDCl}_{3}\right) \delta$ 7.30-7.23 (m, 4H), 6.94-6.87 (m, 6H), $3.95(\mathrm{t}, J=6.5 \mathrm{~Hz}, 4 \mathrm{H}), 3.91-$ $3.80(\mathrm{~m}, 4 \mathrm{H}), 3.40(\mathrm{~m}, 2 \mathrm{H}), 2.49$ (br s, 2H), 1.99-1.93 (m, $4 \mathrm{H}), 1.81-1.75(\mathrm{~m}, 4 \mathrm{H}), 1.72-1.57(\mathrm{~m}, 6 \mathrm{H}), 1.54-1.44(\mathrm{~m}$, 10H); ESI-MS $(\mathrm{m} / \mathrm{z}) 549.4[\mathrm{M}+\mathrm{Na}]^{+}$. Compound 5: ${ }^{1} \mathrm{H}$ NMR $\left(300 \mathrm{MHz}, \mathrm{CDCl}_{3}\right) \delta 7.08(\mathrm{~d}, J=8.4 \mathrm{~Hz}, 4 \mathrm{H}), 6.80$ $(\mathrm{d}, J=8.4 \mathrm{~Hz}, 4 \mathrm{H}), 3.92(\mathrm{t}, J=6.5 \mathrm{~Hz}, 4 \mathrm{H}), 3.89-3.85$ (m, 4H), $3.40(\mathrm{~m}, 2 \mathrm{H}), 2.57(\mathrm{q}, J=7.5 \mathrm{~Hz}, 4 \mathrm{H}), 2.44$ (br s, 2H), $1.98(\mathrm{~m}, 4 \mathrm{H}), 1.78(\mathrm{~m}, 4 \mathrm{H}), 1.69-1.32(\mathrm{~m}, 16 \mathrm{H}), 1.20$ $(\mathrm{t}, J=7.6 \mathrm{~Hz}, 6 \mathrm{H}) ; \mathrm{ESI}-\mathrm{MS}(\mathrm{m} / \mathrm{z}) 605.5[\mathrm{M}+\mathrm{Na}]^{+}$. Compound 8: ${ }^{1} \mathrm{H}$ NMR $\left(400 \mathrm{MHz}, \mathrm{CDCl}_{3}\right) \delta 7.28(\mathrm{~d}, J=$ $8.8 \mathrm{~Hz}, 4 \mathrm{H}), 6.82(\mathrm{~d}, J=8.8 \mathrm{~Hz}, 4 \mathrm{H}), 3.93(\mathrm{t}, J=6.5 \mathrm{~Hz}$, $4 \mathrm{H}), 3.89-3.81(\mathrm{~m}, 4 \mathrm{H}), 3.39(\mathrm{~m}, 2 \mathrm{H}), 2.45$ (br s, $2 \mathrm{H}), 1.98-$ $1.95(\mathrm{~m}, 4 \mathrm{H}), 1.79-1.76(\mathrm{~m}, 4 \mathrm{H}), 1.65-1.58(\mathrm{~m}, 6 \mathrm{H}), 1.46-$ $1.43(\mathrm{~m}, 10 \mathrm{H}), 1.29(\mathrm{~s}, 18 \mathrm{H}) ;{ }^{13} \mathrm{C} \mathrm{NMR}\left(100 \mathrm{MHz}, \mathrm{CDCl}_{3}\right)$ $\delta 156.83,143.12,126.16,113.92,83.14,81.79,73.97,67.80$, $33.37,31.54,29.32,28.97,28.37,26.16,25.43,15.28$; ESIMS $(\mathrm{m} / z) 661.5[\mathrm{M}+\mathrm{Na}]^{+}$. Compound 10: ${ }^{1} \mathrm{H}$ NMR $(300$ $\left.\mathrm{MHz}, \mathrm{CDCl}_{3}\right) \delta 7.24-7.12(\mathrm{~m}, 4 \mathrm{H}), 6.80(\mathrm{~d}, J=8.8 \mathrm{~Hz}$, $4 \mathrm{H}), 3.93(\mathrm{t}, J=6.5 \mathrm{~Hz}, 4 \mathrm{H}), 3.88-3.83(\mathrm{~m}, 4 \mathrm{H}), 3.40(\mathrm{~m}$, 2H), 2.43 (br s, 2H), 1.98-1.96 (m, 4H), 1.80-1.76 (m, 4H), 1.67-0.62 (m, 54H); ESI-MS $(\mathrm{m} / \mathrm{z}) 801.7[\mathrm{M}+\mathrm{Na}]^{+}$. Compound 11: ${ }^{1} \mathrm{H}$ NMR $\left(400 \mathrm{MHz}, \mathrm{CDCl}_{3}\right) \delta 7.10(\mathrm{~d}, J=$ $8.6 \mathrm{~Hz}, 4 \mathrm{H}), 6.81(\mathrm{~d}, J=8.6 \mathrm{~Hz}, 4 \mathrm{H}), 3.91(\mathrm{t}, J=6.5 \mathrm{~Hz}$, $4 \mathrm{H}), 3.89-3.82(\mathrm{~m}, 4 \mathrm{H}), 3.38(\mathrm{~m}, 2 \mathrm{H}), 2.58(\mathrm{q}, J=7.6 \mathrm{~Hz}$, 4H), 2.41 (br s, 2H), 1.97 (m, 4H), 1.77-1.65 (m, 8H), 1.45$1.34(\mathrm{~m}, 20 \mathrm{H}), 1.20(\mathrm{t}, J=7.6 \mathrm{~Hz}, 6 \mathrm{H}) ;{ }^{13} \mathrm{C}$ NMR $(100$ $\left.\mathrm{MHz}, \mathrm{CDCl}_{3}\right) \delta 157.14,136.17,128.64,114.34,83.14$, $81.77,74.04,67.97,33.41,29.62,29.34,29.32,28.97,28.35$, 27.96, 26.02, 25.59, 15.90; ESI-MS $(\mathrm{m} / \mathrm{z}) 661.5[\mathrm{M}+\mathrm{Na}]^{+}$. Compound 12: ${ }^{1} \mathrm{H}$ NMR $\left(500 \mathrm{MHz}, \mathrm{CDCl}_{3}\right) \delta 7.14-7.10$ $(\mathrm{m}, 4 \mathrm{H}), 6.84(\mathrm{ddd}, J=0.65,7.3,8.0 \mathrm{~Hz}, 2 \mathrm{H}), 6.80(\mathrm{~d}, J=$ $8.0 \mathrm{~Hz}, 2 \mathrm{H}), 3.94$ (t, $J=6.5 \mathrm{~Hz}, 4 \mathrm{H}), 3.89-3.82(\mathrm{~m}, 4 \mathrm{H})$, $3.42-3.39(\mathrm{~m}, 2 \mathrm{H}), 2.60(\mathrm{t}, J=7.6 \mathrm{~Hz}, 4 \mathrm{H}), 2.43(\mathrm{br} \mathrm{s}$, 2H), $1.98(\mathrm{~m}, 4 \mathrm{H}), 1.80(\mathrm{~m}, 4 \mathrm{H}), 1.61-1.35(\mathrm{~m}, 24 \mathrm{H}), 0.92$ $(\mathrm{t}, J=7.4 \mathrm{~Hz}, 6 \mathrm{H}) ;{ }^{13} \mathrm{C} \mathrm{NMR}\left(125 \mathrm{MHz}, \mathrm{CDCl}_{3}\right) \delta 156.91$, $131.45,129.75,126.67,120.06,111.06,83.15,81.79,74.00$, $67.62,33.41,32.17,29.96,29.40,28.98,28.36,26.28,25.44$, 22.65, 14.05; ESI-MS $(\mathrm{m} / \mathrm{z}) 661.5[\mathrm{M}+\mathrm{Na}]^{+}$.

(D) Compounds 6, 9, and 13. The synthetic procedures of these compounds are described taking compound $\mathbf{6}$ as an example (Scheme 1E). To a solution of 1-(tert-butyldimethylsilyloxy)-3-butyne (730 mg, $4.0 \mathrm{mmol})$ in dry THF (6 mL) at $-78{ }^{\circ} \mathrm{C}$ was added a solution of $n-\mathrm{BuLi}(1.6 \mathrm{M}$ in hexane, $2.4 \mathrm{~mL}, 3.84 \mathrm{mmol})$. After $30 \mathrm{~min}, \mathrm{BF}_{3} \cdot \mathrm{Et}_{2} \mathrm{O}(0.48 \mathrm{~mL}, 3.84$ mmol) was added, and the mixture was stirred for $20 \mathrm{~min}$. To the mixture was added a solution of $\mathbf{2 0}(180 \mathrm{mg}, 0.80$ $\mathrm{mmol})$ in THF $(2.5 \mathrm{~mL})$, and the resultant mixture was stirred for $50 \mathrm{~min}$ at -78 to $-10{ }^{\circ} \mathrm{C}$. The reaction mixture was worked up with saturated aqueous $\mathrm{NH}_{4} \mathrm{Cl}$, washed with brine, dried, and concentrated. The residue was purified by silica gel column chromatography (hexane-EtOAc, 1:1) to give the diol (385 mg, 82\%). To a mixture of the diol (440 mg, $0.74 \mathrm{mmol})$ and $\mathrm{N}, \mathrm{N}$-diisopropylethylamine in $\mathrm{CH}_{2} \mathrm{Cl}_{2}(7$ $\mathrm{mL})$ at $0{ }^{\circ} \mathrm{C}$ was added chloromethyl methyl ether $(480 \mathrm{mg}$, $5.92 \mathrm{mmol}$ ), and the mixture was stirred for $10 \mathrm{~h}$ at room temperature. The reaction mixture was quenched with saturated aqueous $\mathrm{NH}_{4} \mathrm{Cl}$, washed with brine, dried, and concentrated. The residue was purified by silica gel column chromatography (hexanes-EtOAc, 4:1) to give $\mathbf{2 2}(490 \mathrm{mg}$, 97\%). A mixture of $22(490 \mathrm{mg}, 0.72 \mathrm{mmol})$ and $10 \% \mathrm{Pd} / \mathrm{C}$ $(15 \mathrm{mg})$ in ethanol $(10 \mathrm{~mL})$ was stirred under a $\mathrm{H}_{2}$ 
atmosphere at room temperature for $8 \mathrm{~h}$. The crude product was purified by silica gel column chromatography (hexaneEtOAc, 9:1) to afford the MOM derivative (450 mg, 91\%). To a solution of the MOM derivative $(450 \mathrm{mg}, 0.66 \mathrm{mmol})$ in dry THF $(11 \mathrm{~mL})$ at $0{ }^{\circ} \mathrm{C}$ was added TBAF $(1.0 \mathrm{M}$ in THF, $3.93 \mathrm{~mL}, 3.93 \mathrm{mmol}$ ), and the resultant mixture was stirred for $1 \mathrm{~h}$ at room temperature. The reaction mixture was worked up with saturated aqueous $\mathrm{NH}_{4} \mathrm{Cl}$, washed with brine, dried, and concentrated. The residue was purified by silica gel column chromatography (hexane-EtOAc, 95:5) to give the desilylated derivative (311 mg, 99\%). To a mixture of this compound (311 $\mathrm{mg}, 0.68 \mathrm{mmol}$ ) and $\mathrm{Et}_{3} \mathrm{~N}$ $(850 \mathrm{mg})$ in dry THF $(15 \mathrm{~mL})$ at $0{ }^{\circ} \mathrm{C}$ was added methanesulfonyl chloride $(640 \mathrm{mg}, 5.58 \mathrm{mmol})$, and the mixture was stirred for $1 \mathrm{~h}$. The reaction mixture was quenched, washed with brine, dried, and concentrated. The residue was purified by silica gel column chromatography (hexane-EtOAc, 7:3) to give 23 (380 mg, 95\%). To a solution of 23 (101 $\mathrm{mg}, 0.16 \mathrm{mmol})$ in acetone $(3 \mathrm{~mL})$ was added sodium phenoxide (1.2 equiv), and the mixture was stirred for $4 \mathrm{~h}$ at $60^{\circ} \mathrm{C}$. The reaction mixture was quenched with brine, dried, and concentrated. The residue was purified by silica gel column chromatography (hexane-EtOAc, 7:3) to give $24(36.7 \mathrm{mg}, 37 \%)$. To a solution of $24(36.7 \mathrm{mg}$, $0.06 \mathrm{mmol})$ in acetone $(2 \mathrm{~mL})$ was added sodium $4-n$ butylphenoxide ( 2.5 equiv), and the resultant mixture was stirred for $5 \mathrm{~h}$ at $60{ }^{\circ} \mathrm{C}$. The reaction mixture was quenched with brine, dried, and concentrated. The residue was purified by silica gel column chromatography (hexane-EtOAc, 7:3) to give 6 (34 mg, 85\%). ${ }^{1} \mathrm{H}$ NMR (300 $\left.\mathrm{MHz}, \mathrm{CDCl}_{3}\right) \delta$ 7.29-7.24 (m, 2H), $7.06(\mathrm{~d}, J=8.6 \mathrm{~Hz}, 2 \mathrm{H}), 6.94-6.87$ $(\mathrm{m}, 3 \mathrm{H}), 6.80(\mathrm{~d}, J=8.6 \mathrm{~Hz}, 2 \mathrm{H}), 3.92(\mathrm{t}, J=6.5 \mathrm{~Hz}, 4 \mathrm{H})$, $3.92-3.82(\mathrm{~m}, 4 \mathrm{H}), 3.40(\mathrm{~m}, 2 \mathrm{H}), 2.53(\mathrm{t}, J=7.6 \mathrm{~Hz}, 2 \mathrm{H})$, 2.51 (br s, 2H), 1.99-1.96 (m, 4H), 1.81-1.75 (m, 6H), $1.68-1.33(\mathrm{~m}, 18 \mathrm{H}), 0.91(\mathrm{t}, J=7.3 \mathrm{~Hz}, 3 \mathrm{H})$. ESI-MS $(\mathrm{m} /$ z) $605.5[\mathrm{M}+\mathrm{Na}]^{+}$.

Compounds $\mathbf{9}$ and $\mathbf{1 3}$ were synthesized by the same procedures using the corresponding phenoxides. Compound 9: ${ }^{1} \mathrm{H}$ NMR $\left(400 \mathrm{MHz}, \mathrm{CDCl}_{3}\right) \delta 7.20-7.10(\mathrm{~m}, 2 \mathrm{H}), 7.06$ $(\mathrm{d}, J=8.6 \mathrm{~Hz}, 2 \mathrm{H}), 6.80(\mathrm{~d}, J=8.6 \mathrm{~Hz}, 4 \mathrm{H}), 3.92(\mathrm{t}, J=$ $6.5 \mathrm{~Hz}, 4 \mathrm{H}), 3.87-3.82(\mathrm{~m}, 4 \mathrm{H}), 3.40(\mathrm{~m}, 2 \mathrm{H}), 2.53(\mathrm{t}, J=$ $7.6 \mathrm{~Hz}, 2 \mathrm{H}), 2.42$ (br s, 2H), 1.99-1.96 (m, 2H), 1.80$1.76(\mathrm{~m}, 4 \mathrm{H}), 1.66-0.72(\mathrm{~m}, 38 \mathrm{H}), 0.91(\mathrm{t}, J=7.3 \mathrm{~Hz}, 6 \mathrm{H})$; ESI-MS $(\mathrm{m} / \mathrm{z}) 731.6[\mathrm{M}+\mathrm{Na}]^{+}$. Compound 13: ${ }^{1} \mathrm{H}$ NMR $\left(400 \mathrm{MHz}, \mathrm{CDCl}_{3}\right) \delta 7.11(\mathrm{~d}, J=7.4 \mathrm{~Hz}, 2 \mathrm{H}), 7.07$ (d, $J=$ $8.6 \mathrm{~Hz}, 2 \mathrm{H}), 6.85$ (ddd, $J=0.65,7.4,8.6 \mathrm{~Hz}, 1 \mathrm{H}), 6.81-$ $6.78(\mathrm{~m}, 3 \mathrm{H}), 3.94(\mathrm{t}, J=6.5 \mathrm{~Hz}, 2 \mathrm{H}), 3.92(\mathrm{t}, J=6.5 \mathrm{~Hz}$, $2 \mathrm{H}), 3.89-3.82(\mathrm{~m}, 4 \mathrm{H}), 3.40(\mathrm{~m}, 2 \mathrm{H}), 2.60(\mathrm{t}, J=7.6 \mathrm{~Hz}$, 2H), $2.53(\mathrm{t}, J=7.6 \mathrm{~Hz}, 2 \mathrm{H}), 2.45$ (br s, 2H), 1.97-1.96 $(\mathrm{m}, 4 \mathrm{H}), 1.80-1.77(\mathrm{~m}, 4 \mathrm{H}), 1.59-1.51(\mathrm{~m}, 12 \mathrm{H}), 1.47-$ $1.32(\mathrm{~m}, 12 \mathrm{H}), 0.94-0.89(\mathrm{~m}, 6 \mathrm{H}) ;{ }^{13} \mathrm{C}$ NMR $(100 \mathrm{MHz}$, $\left.\mathrm{CDCl}_{3}\right) \delta 157.11,156.91,129.76,129.91,126.68,120.27$, $114.26,111.68,83.15,81.80,74.02,67.86,33.91,33.42$, 29.32, 28.98, 28.37, 26.29, 25.44, 22.66, 22.31, 14.05. ESIMS $(m / z) 661.5[\mathrm{M}+\mathrm{Na}]^{+}$.

(E) Compound 14. The synthetic procedures of compound 14 are outlined in Scheme 1F. To a solution of 6-(tertbutyldimethylsilyloxy)-1-hexyne (300 mg, $1.4 \mathrm{mmol}$ ) in dry toluene $(2.0 \mathrm{~mL})$ at $0{ }^{\circ} \mathrm{C}$ was added a solution of $n$-BuLi (1.6 $\mathrm{M}$ in hexane, $1.1 \mathrm{~mL}, 1.4 \mathrm{mmol}$ ). After $15 \mathrm{~min}, \mathrm{Et}_{2} \mathrm{AlCl}$ (1.0 $\mathrm{M}$ in hexane, $1.4 \mathrm{~mL}, 1.4 \mathrm{mmol}$ ) was added, and the mixture was stirred for $1 \mathrm{~h}$. To the mixture was added a solution of $\mathbf{2 5}$ (50 mg, $0.14 \mathrm{mmol}$ ), which is the same sample as that synthesized previously (11), in dry toluene $(1.8 \mathrm{~mL})$, and the resultant mixture was stirred for $1.5 \mathrm{~h}$ at $0{ }^{\circ} \mathrm{C}$. The reaction mixture was worked up with saturated aqueous $\mathrm{NH}_{4} \mathrm{Cl}$, washed with brine, dried, and concentrated. The residue was purified by silica gel column chromatography (hexane-EtOAc, 1:1) to give $\mathbf{2 6}$ (41 mg, 52\%). A mixture of 26 (41 $\mathrm{mg}, 0.35 \mathrm{mmol})$ and $10 \% \mathrm{Pd} / \mathrm{C}(4 \mathrm{mg})$ in ethanol $(5 \mathrm{~mL})$ was stirred under a $\mathrm{H}_{2}$ atmosphere at room temperature for $8 \mathrm{~h}$. The reaction mixture was filtered over Celite, solvents were removed under vacuum, and the crude product was passed through a short bed of silica gel. To a solution of this product $(35 \mathrm{mg}, 0.061 \mathrm{mmol})$ in dry THF $(3 \mathrm{~mL})$ at $0{ }^{\circ} \mathrm{C}$ was added TBAF (1.0 M in THF, $\left.0.24 \mathrm{~mL}, 0.24 \mathrm{mmol}\right)$, and the resultant mixture was stirred for $1.5 \mathrm{~h}$ at room temperature. The reaction was quenched by the addition of saturated aqueous $\mathrm{NH}_{4} \mathrm{Cl}$, washed with brine, dried, and concentrated. The crude product was purified by silica gel column chromatography (EtOAc, 100\%) to afford 27 (25 $\mathrm{mg}, 91 \%)$. A mixture of 27 (25 mg, $36 \mu \mathrm{mol})$, D-(+)-biotin (20 mg, $83 \mu \mathrm{mol})$, EDC (18 mg, $94 \mu \mathrm{mol})$, and DMAP (2 $\mathrm{mg}, 17 \mu \mathrm{mol})$ in dry $\mathrm{CH}_{2} \mathrm{Cl}_{2}$ was stirred at room temperature for 4 days. The reaction mixture was filtered over Celite, solvents were removed under vacuum, and the crude product was purified by silica gel column chromatography (EtOAc, $100 \%)$ to afford $14(25 \mathrm{mg}, 66 \%) .{ }^{1} \mathrm{H} \mathrm{NMR}(300 \mathrm{MHz}$, $\left.\mathrm{CDCl}_{3}\right) \delta 5.12$ (br s, $\left.1 \mathrm{H}\right), 4.93$ (br s, $\left.1 \mathrm{H}\right), 4.51(\mathrm{~m}, 1 \mathrm{H})$, $4.32(\mathrm{~m}, 1 \mathrm{H}), 4.06(\mathrm{t}, J=6.6 \mathrm{~Hz}, 2 \mathrm{H}), 3.94-3.82(\mathrm{~m}, 4 \mathrm{H})$, $3.38(\mathrm{~m}, 2 \mathrm{H}), 3.16(\mathrm{~m}, 1 \mathrm{H}), 2.93(\mathrm{dd}, J=5.0,12.6 \mathrm{~Hz}$, $1 \mathrm{H}), 2.74(\mathrm{~d}, J=12.6 \mathrm{~Hz}, 1 \mathrm{H}), 2.58(\mathrm{br} \mathrm{s}, 2 \mathrm{H}), 2.32$ (t, $J=$ $7.3 \mathrm{~Hz}, 2 \mathrm{H}), 1.97(\mathrm{~m}, 4 \mathrm{H}), 1.74-1.61$ (m, 10H), $1.51-1.25$ $(\mathrm{m}, 30 \mathrm{H}), 0.87(\mathrm{t}, J=6.9 \mathrm{~Hz}, 3 \mathrm{H})$. ESI-MS $(\mathrm{m} / \mathrm{z}) 705.5[\mathrm{M}$ $+\mathrm{Na}]^{+}$.

Measurement of Complex I Activity. Bovine heart submitochondrial particles (SMP) were prepared by the method of Matsuno-Yagi and Hatefi (14) using a sonication medium containing $0.25 \mathrm{M}$ sucrose, $1 \mathrm{mM}$ succinate, $1.5 \mathrm{mM}$ ATP, $10 \mathrm{mM} \mathrm{MgCl}_{2}, 10 \mathrm{mM} \mathrm{MnCl}$, and $10 \mathrm{mM}$ Tris- $\mathrm{HCl}(\mathrm{pH}$ 7.4) and stored in a buffer containing $0.25 \mathrm{M}$ sucrose and $10 \mathrm{mM}$ Tris- $\mathrm{HCl}\left(\mathrm{pH} \mathrm{7.4)}\right.$ at $-84{ }^{\circ} \mathrm{C}$. The $\mathrm{NADH}$ oxidase activity in SMP was followed spectrometrically with a Shimadzu UV-3000 (340 nm, $\left.\epsilon=6.2 \mathrm{mM}^{-1} \mathrm{~cm}^{-1}\right)$ at 25 ${ }^{\circ} \mathrm{C}$. The reaction medium $(2.5 \mathrm{~mL})$ contained $0.25 \mathrm{M}$ sucrose, $1 \mathrm{mM} \mathrm{MgCl}_{2}$, and $50 \mathrm{mM}$ phosphate buffer ( $\mathrm{pH} \mathrm{7.4).} \mathrm{The}$ final mitochondrial protein concentration was $30 \mu \mathrm{g}$ of protein $/ \mathrm{mL}$. The reaction was started by adding $50 \mu \mathrm{M}$ NADH after the equilibration of SMP with inhibitor(s) for $5 \mathrm{~min}$. The $\mathrm{IC}_{50}$ values were averaged from three independent experiments. For some test compounds, the inhibition of $\mathrm{NADH}-\mathrm{Q}_{1}$ oxidoreductase activity was also determined under the same experimental conditions, except that the reaction medium contained $0.2 \mu \mathrm{M}$ antimycin A and $2 \mathrm{mM} \mathrm{KCN}$.

Fluorescence Quenching Titration. Fluorescence emission spectra were recorded on a Hitachi RF-5000 spectrophotometer at $25^{\circ} \mathrm{C}(15)$. For fluorescence quenching measurements, SMP were diluted in phosphate buffer $(0.25 \mathrm{M}$ sucrose, $2 \mathrm{mM} \mathrm{KCN}, 1 \mathrm{mM} \mathrm{MgCl}_{2}$, and $50 \mathrm{mM}$ sodium phosphate, $\mathrm{pH} 7.4$ ) to $1.25 \mathrm{mg}$ of protein $/ \mathrm{mL}$, corresponding to about $75 \mathrm{nM}$ complex I. 6-Amino-4-(4-tert-butylphenethylamino)quinazoline (AQ), which is the same sample as that synthesized previously (15), was added to a stirred quartz cuvette from ethanol stock solution. The background fluo- 
rescence resulting from SMP without AQ was subtracted from the spectral data to correct for the effect of SMP. The excitation and emission wavelengths were set at 360 and 480 $\mathrm{nm}$, respectively, with a slit width of $5 \mathrm{~nm}$.

Measurement of Superoxide Production. Superoxide production was determined by the following superoxidedependent oxidation of epinephrine to adrenochrome (16) with a Shimadzu UV-3000 spectrophotometer $(485-575 \mathrm{~nm}$, $\left.\epsilon=2.96 \mathrm{mM}^{-1} \mathrm{~cm}^{-1}\right)$ at $25{ }^{\circ} \mathrm{C}$. The reaction medium $(2.5$ $\mathrm{mL}$ ) contained $0.25 \mathrm{M}$ sucrose, $1 \mathrm{mM}$ epinephrine, $1 \mathrm{mM}$ EDTA, $1 \mu \mathrm{M}$ catalase, and $10 \mathrm{mM}$ Tris- $\mathrm{HCl}$ buffer ( $\mathrm{pH}$ 7.4). The final protein concentration of SMP was $0.3 \mathrm{mg} / \mathrm{mL}$. The reaction was started by adding $100 \mu \mathrm{M}$ NADH after the equilibration of SMP with $1.2 \mu \mathrm{M}$ inhibitor for $4 \mathrm{~min}$. Superoxide dismutase was used at a final concentration of 60 units/mL to give assay specificity.

ELISA Measurement of Binding of Biotinylated DlacAcetogenin to Various Lipids. The binding of biotinylated $\Delta$ lac-acetogenin to various lipids was measured by ELISA as described previously (17). In brief, $50 \mu \mathrm{L}$ of lipid (10 $\mu \mathrm{M})$ in ethanol was added to the well of a microtiter plate (Immulon 1; Dynatech Loboratories, Alexandria, VA). After the solvent was evaporated at room temperature, $200 \mu \mathrm{L}$ of $30 \mathrm{mg} / \mathrm{mL}$ bovine serum albumin in Tris-buffered saline (TBS, $10 \mathrm{mM}$ Tris- $\mathrm{HCl}, \mathrm{pH} 7.4,150 \mathrm{mM} \mathrm{NaCl}$ ) was added to each well. After washing, the wells were incubated with $50 \mu \mathrm{L}$ of $100 \mathrm{nM}$ biotinylated $\Delta$ lac-acetogenin in TBS containing $10 \mathrm{mg} / \mathrm{mL} \mathrm{BSA} \mathrm{(1 \%} \mathrm{BSA-TBS)} \mathrm{for} 2 \mathrm{~h}$ at room temperature. The bound $\Delta$ lac-acetogenin was detected by incubation with peroxidase-conjugated streptavidin. The intensity of the color developed with $o$-phenylenediamine as a substrate was measured with an ELISA reader (BioRad, model 550 microplate reader), reading the absorption at $490 \mathrm{~nm}$ with reference at $630 \mathrm{~nm}$.

Materials. Piericidin A and bullatacin were generous gifts from Drs. S. Yoshida (The Institute of Physical and Chemical Research, Japan) and J. McLaughlin (Purdue University, West Lafayette, IN), respectively. Other chemicals were commercial products of analytical grade.

\section{RESULTS}

Crucial Structural Factors in the THF Ring Moiety. Structure-activity studies for common acetogenins have demonstrated that both the number of THF rings and the stereochemistry around the hydroxylated THF ring(s) are not important structural factors required for the potent inhibition of the bovine heart mitochondrial complex I (9-13). Although the reason the number of THF rings is not crucial is still unclear, concerning the stereochemistry, an exhaustive conformational space search analysis showed that some stable conformations of the adjacent bis-THF rings of stereoisomers are in fairly good superimposition due to the flexibility of this moiety (9). As we synthesized no stereoisomers of $\Delta$ lacacetogenins in the previous study (8), the effect of the stereochemistry surrounding the hydroxylated THF rings on the inhibition remained unknown. Therefore, we synthesized compound $\mathbf{2}$ (enantiomer of $\mathbf{1}$ ), which has the $S$ configuration at all chiral centers. The inhibition of compound $\mathbf{2}$ was about 5 -fold less potent than that of compound 1 (Table 1). At first sight, this difference seems to be not so significant, but it should be noted that inhibitory potencies of stereoisomers
Table 1: Summary of the Inhibitory Potencies $\left(\mathrm{IC}_{50}\right)$ of the Test Compounds $^{a}$

\begin{tabular}{clll}
\hline compd & \multicolumn{1}{c}{$\mathrm{IC}_{50}(\mathrm{nM})$} & \multicolumn{1}{c}{ compd } & \multicolumn{1}{c}{$\mathrm{IC}_{50}(\mathrm{nM})$} \\
\hline $\mathbf{1}$ & $1.6( \pm 0.07)$ & $\mathbf{9}$ & $150( \pm 9)$ \\
$\mathbf{2}$ & $7.5( \pm 0.3)$ & $\mathbf{1 0}$ & $>500^{b}$ \\
$\mathbf{3}$ & $>25000^{b}$ & $\mathbf{1 1}$ & $3.0( \pm 0.1)$ \\
$\mathbf{4}$ & $1.4( \pm 0.06)$ & $\mathbf{1 2}$ & $>1000^{b}$ \\
$\mathbf{5}$ & $1.1( \pm 0.04)$ & $\mathbf{1 3}$ & $16( \pm 0.4)$ \\
$\mathbf{6}$ & $0.91( \pm 0.03)$ & $\mathbf{1 4}$ & $5.2( \pm 0.2)$ \\
$\mathbf{7}$ & $0.83( \pm 0.04)$ & piericidin A & $1.3( \pm 0.05)$ \\
$\mathbf{8}$ & $1.0( \pm 0.04)$ & bullatacin & $0.85( \pm 0.03)$ \\
\hline
\end{tabular}

${ }^{a}$ The $\mathrm{IC}_{50}$ value is the molar concentration needed to reduce the control NADH oxidase activity $\left[0.60-0.65 \mu \mathrm{mol}\right.$ of NADH $\mathrm{min}^{-1}(\mathrm{mg}$ of protein $)^{-1}$ ] in SMP by half. Values are the means \pm SD of at least three independent experiments. ${ }^{b}$ The experiment above the concentration was impractical because of the solubility limit.

of common acetogenins are almost identical irrespective of the number of THF rings $(9,12,13)$. Therefore, this result indicates that the effect of stereochemistry surrounding the bis-THF rings is more important for $\Delta$ lac-acetogenin than for common acetogenins.

Next, to examine the effect of the number of THF rings, we synthesized compound $\mathbf{3}$ possessing one THF ring with two flanking hydroxy groups. Unexpectedly, this derivative completely lost the activity, indicating that the presence of adjacent bis-THF rings, most probably two ether oxygen atoms, is essential for the inhibitory action of $\Delta$ lacacetogenins. It is noteworthy that the $\mathrm{IC}_{50}$ values of stereoisomers of cis-solamin and corossoline, which are common acetogenins having one THF ring with various stereochemistries around the hydroxylated THF ring, are $1.5-2.0 \mathrm{nM}$ under the same experimental conditions (13). These results along with the previous structure-activity study $(8)$ indicate that structural factors required for the inhibitory action are entirely different between $\Delta$ lac-acetogenins and common acetogenins.

Synthetic Development of New Dlac-Acetogenins. All $\Delta$ lac-acetogenins synthesized in the previous study (8) have straight alkyl chains as the tails. It is therefore unknown whether the tails must be flexible alkyl chains to elicit potent inhibition. We here synthesized derivatives that have a phenyl ether structure in the middle of the tail (compounds 4-14). The stereochemistry around the hydroxylated bis-THF ring moiety of the derivatives was fixed as identical to that of the original $\Delta$ lac-acetogenins, i.e., threo/trans/threo/trans/ threo. Compound $\mathbf{4}$ possessing a nonsubstituted phenyl ether in both tails exhibited strong activity comparable to that of compound $\mathbf{1}$. This and the following derivatives studied in this work elicited no inhibition of NADH-HAR oxidoreductase activity and inhibited $\mathrm{NADH}-\mathrm{Q}_{1}$ oxidoreductase activity at concentrations comparable to those in the NADH oxidase assay (data not shown).

The introduction of alkyl substituent(s) into the para position of the benzene ring of compound 4 further, but slightly, enhanced the activity (compounds 5-8). In particular, the inhibitory potency of compound 7 possessing two $n$-butyl groups was equivalent to that of bullatacin, one of the most potent inhibitors of bovine complex I $(4,6,9)$. Replacement of the $n$-butyl group of compound 7 with a bulky tert-butyl group little affected the activity (compound 7 vs 8). Thus, it is obvious that the tail portion of $\Delta$ lacacetogenins does not need to be a flexible alkyl chain. 
Further lengthening of the para substituent(s) beyond the $n$-butyl group resulted in a significant loss of the activity (compounds 9 and 10). Although this result seems to be somewhat peculiar, a similar tendency was observed for the original $\Delta$ lac-acetogenins, which have sufficiently long alkyl tails (8). An excessive increase in hydrophobicity of the tail may be rather adverse to the activity probably due to some sort of trapping in the hydrophobic lipid bilayer of the membrane. The inhibitory potency of compound 11, which has the same number of total carbon atoms as 7 , was slightly decreased by lengthening the distance between the bis-THF rings and phenyl ether portion by two carbon atoms (compound $\mathbf{7}$ vs 11).

Unexpectedly, compound $\mathbf{1 2}$ possessing an $n$-butyl group at the ortho position of both tails almost completely lost the activity, though this loss was significantly recovered by replacing one of the two $o$-n-butyl groups with a $p$ - $n$-butyl group (compound 12 vs 13). The drastic loss of the activity of $\mathbf{1 2}$ will be discussed later in connection with the function of the tail moiety.

Double-Inhibitor Titration of Complex I Activity. Doubleinhibitor titration of steady-state complex I activity is useful to examine whether two inhibitors of interest bind to different sites $(8,15)$. If the binding sites are identical, the extent of inhibition by the two will be additive, and the maximum inhibition by one inhibitor will be attained at a lower concentration than that without the additional inhibitor. However, if the binding sites are not identical and there is no cooperativity between the two sites, the inhibition will not be additive, and the concentration giving maximum inhibition by one inhibitor will not be affected irrespective of the presence of the additional inhibitor.

Using bullatacin as the standard inhibitor because of its very high binding affinity to bovine complex I $\left(K_{\mathrm{d}}=2-5\right.$ $\mathrm{nM}$; ref 6 ) and the resulting reproducible linearity of the titration curve, we previously showed that the effects of compound $\mathbf{1}$ and bullatacin are not additive (8). To examine the behavior of compound $\mathbf{7}$, which is the most potent inhibitor among the newly synthesized $\Delta$ lac-acetogenins, we also performed the double-inhibitor titration of NADH oxidase activity with bullatacin (Figure 2A). In the presence of compound 7 giving about $30 \%$ and $60 \%$ inhibition, complete inhibition by bullatacin was achieved at an identical concentration to that obtained without 7 , indicating no additivity of inhibition for the two inhibitors. As a control, a titration of bullatacin in combination with diphenyleneiodonium, which is known to inhibit the electron input into complex I (18), was carried out and, as expected, indicated nonadditive behavior comparable to that observed for compound 7 (data not shown). A titration of bullatacin in combination with a synthetic natural-type acetogenin ("lead compound" in ref 8 ) was carried out and indicated additive behavior (Figure 2B). These results strongly suggest that the binding site of $\Delta$ lac-acetogenins is different from that of common acetogenins.

Competition Test by Fluorescence Quenching Titration. Fluorescent ligand binding (6) and photoaffinity labeling (19, 20) studies indicated that the specific binding of a certain marker ligand to complex I is completely suppressed in the presence of an excess amount of competitors (i.e., other complex I inhibitors). These findings are consistent with the model of inhibitor binding sites proposed by Okun et al. (6),
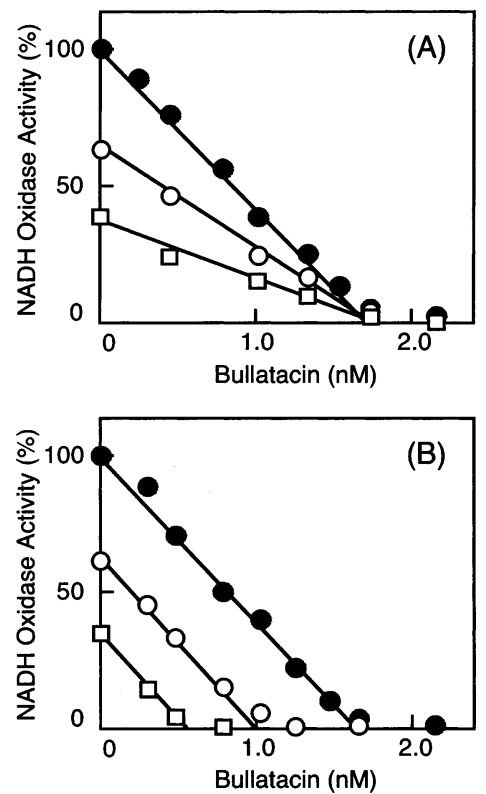

FIGURE 2: Inhibition of NADH oxidase activity by bullatacin. Titration by bullatacin alone is shown by closed circles. Titration was performed in the presence of compound 7 (panel A: $0.47 \mathrm{nM}$, open circles; $0.94 \mathrm{nM}$, open squares) or the lead compound shown in ref 8 (panel B: $0.45 \mathrm{nM}$, open circles; $0.9 \mathrm{nM}$, open squares). The control NADH oxidase activities in SMP were $0.60-0.65 \mu \mathrm{mol}$ of NADH $\min ^{-1}$ (mg of protein $)^{-1}$. Data shown are representative of three independent experiments.

wherein a wide variety of inhibitors share a common large binding domain with partially overlapping sites. However, under the experimental conditions reported in the literature, one cannot rule out the possibility that the competitors prevent the binding of a certain marker ligand by inducing a conformational change in complex I, rather than occupying the same binding domain (21). In the previous study using a fluorescent inhibitor (AQ) with a high quantum yield (15), we also confirmed the suppression of specific AQ binding to the enzyme in the presence of an excess amount of other complex I inhibitors but argued that the apparent competitive behavior among various complex I inhibitors cannot be explained simply on the basis of competition for the same binding domain because AQ bound to the enzyme was not displaced by subsequent addition of an increasing amount of competitors in the concentration range expected from the relative magnitude of the $K_{\mathrm{d}}$ values of AQ and competitors.

To examine whether compound $\mathbf{7}$ and AQ bind to the same binding domain, we examined the effect of compound 7 on the binding of AQ to complex I, as done in refs 6 and 15 . The typical titration given in Figure 3 shows that the fluorescence of AQ is significantly quenched when AQ is bound to the enzyme (closed circles). When SMP were preincubated with an excess amount of piericidin $\mathrm{A}(0.5 \mu \mathrm{M})$, the fluorescence of added AQ was not quenched (closed squares), indicating that AQ cannot bind to the specific binding site in the presence of piericidin $\mathrm{A}$, being consistent with the reported observation $(6,15)$. It should be noted that other ordinary inhibitors (bullatacin, rotenone, fenpyroximate, pyridaben, and cap-44) also completely suppress the binding of AQ to the enzyme (15). In contrast, the presence of an excess amount of compound $7(0.5 \mu \mathrm{M})$ did not suppress AQ binding (open circles), although the fluorescence intensity was slightly greater than that in the absence of 7 . A 


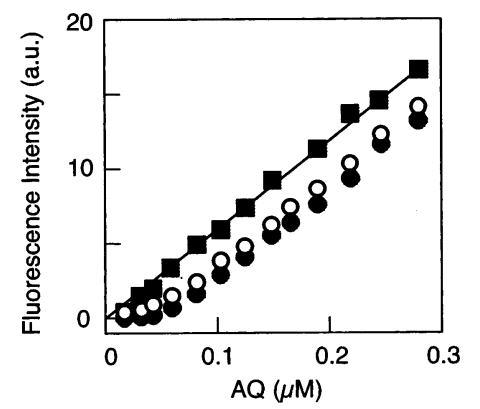

FIGURE 3: Fluorescence titration of AQ with SMP. The ethanol solution of AQ (closed circles) was sequentially added to the suspension of SMP (1.25 mg of protein $/ \mathrm{mL})$. After $4 \mathrm{~min}$ incubation at each concentration, fluorescence emission was determined. SMP were preincubated with $0.5 \mu \mathrm{M}$ piericidin (closed squares) or 0.5 $\mu \mathrm{M}$ compound 7 (open circles). Data shown are representative of three independent experiments.

further increase in compound 7 concentrations did not affect the fluorescence titrations (data not shown). Among the complex I inhibitors we have tested, compound $\mathbf{7}$ is the only one that could not suppress AQ binding. These results also indicate that the binding site of compound 7 is different from that of ordinary complex I inhibitors.

Effects of $\Delta$ lac-Acetogenin on Superoxide Production. Superoxide is produced by the single electron reduction of oxygen by an electron carrier within the mitochondrial electron transport chain. The reductant of oxygen producing superoxide in complex I is not known, and published results are highly conflicting. Recently, Lambert and Brand (22) suggested that the major site of superoxide production in complex $I$ is in the region of the ubiquinone reduction site on the basis of the observation that different complex I inhibitors such as rotenone and piericidin $\mathrm{A}$ and high concentrations of myxothiazol gave different rates of superoxide production during the forward electron transport. If the main or only site of the high superoxide production is upstream of the ubiquinone reduction site (i.e., iron-sulfur centers or flavin), addition of any quinone site inhibitor should result in the same rate of superoxide production, but this was not the case (22). It is therefore likely that the rate of superoxide production may differ, reflecting a slight difference in the binding sites (or manners) of inhibitors.

We measured therefore the rate of superoxide production induced by compound 7 using SMP and compared it with that induced by ordinary complex I inhibitors (Figure 4). We preliminarily confirmed that each inhibitor caused maximal inhibition of complex I activity at the concentration used. It is obvious that the rate of superoxide production induced by compound 7 is remarkably lower than that induced by ordinary complex I inhibitors including bullatacin. A similar result was observed for compound $\mathbf{1}$ (data not shown). These results strongly suggest that effects of $\Delta$ lacacetogenins on the redox status of the free radical intermediate in complex I, probably the region of the ubisemiquinone binding site, are fairly different from those of ordinary complex I inhibitors. The rates of superoxide production induced by ordinary inhibitors were not identical, whereas the difference in the rates was less significant than that determined as hydrogen peroxide generation with intact mitochondria (22).

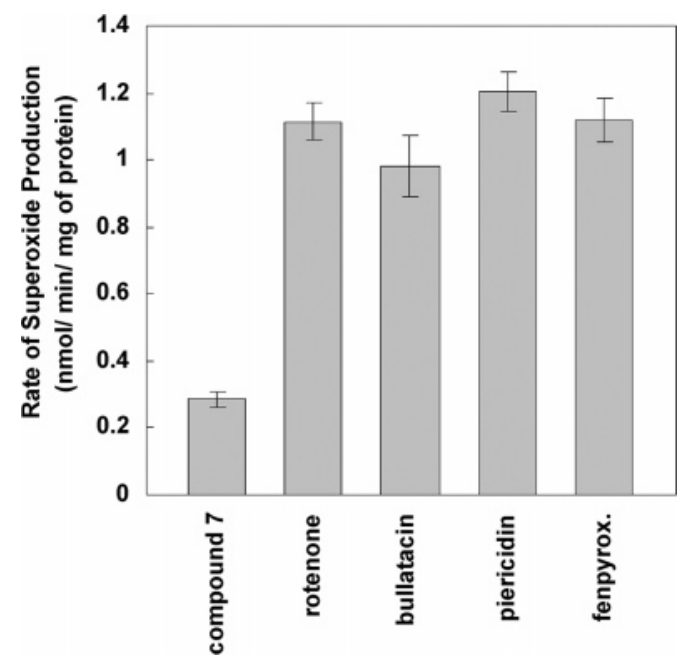

FIGURE 4: Rates of superoxide production induced by various complex I inhibitors. The reaction was started by adding $100 \mu \mathrm{M}$ NADH after the equilibration of SMP $(0.3 \mathrm{mg}$ of protein $/ \mathrm{mL})$ with $1.2 \mu \mathrm{M}$ inhibitor for $4 \mathrm{~min}$. Values are the means $\pm \mathrm{SD}$ of three independent experiments.

\section{DISCUSSION}

The present structure-activity study along with the previous results $(8)$ indicated that the structural factors required for the inhibitory action of $\Delta$ lac-acetogenins are entirely different from those of common acetogenins. The enzyme recognizes the hydroxylated bis-THF ring moiety of $\Delta$ lac-acetogenins much more strictly than that of common acetogenins, especially the number of THF rings and the presence of two hydroxy groups. This finding strongly suggests that the mode of inhibition of $\Delta$ lac-acetogenins is different from that of common acetogenins. This idea was verified by the result of the double-inhibitor titration. Moreover, the displacement test using a fluorescent ligand and the investigation of the effects on superoxide production also indicate that the binding site of $\Delta$ lac-acetogenins is fairly different from that of ordinary complex I inhibitors. Taken together, our results clearly demonstrate that $\Delta$ lac-acetogenins are a novel type of inhibitor acting at the terminal electron-transfer step of complex I. As the present study showed that a substituted benzene ring can be introduced into the tail portion without a loss of activity, it is worth carrying out further wide structural modifications of $\Delta$ lacacetogenins for the purpose of developing useful molecular probes.

In the previous study (8), we argued that the balance of hydrophobicity of the alkyl tails is an important structural factor of $\Delta$ lac-acetogenins to regulate the precise location of the hydroxylated bis-THF ring moiety, which may serve as a hydrogen bond donor and/or acceptor, in the enzyme. The drastic change in the inhibitory potency of the three butyl derivatives (compounds $\mathbf{7 , 8}$, and 12) is suggestive of the function of the tail portion of $\Delta$ lac-acetogenins. Namely, although a bulky $p$-tert-butyl derivative (8) maintained strong activity equivalent to that of a $p$ - $n$-butyl derivative (7), an $o$ - $n$-butyl derivative (12) almost completely lost the activity. It seems to be difficult to explain this result on the assumption that the tails of $\Delta$ lac-acetogenins merely partition into the hydrophobic lipid membrane environment for two reasons; first, the partition behavior of a branched alkyl group (a tert-butyl group in this case) into ordered lipid membrane 
is energetically less favorable than that of the corresponding straight alkyl group (i.e., $n$-butyl group) (23), and second, the steric effects of ortho and para substituents on the partition behavior may be comparable as shown for the partition behavior of various substituted phenols in the lecithin liposome/water system (24). It is therefore likely that the tails directly interact with the hydrophobic domain of complex I rather than merely partitioning into lipid membrane environment, whereupon the enzyme recognizes a difference in molecular shape of the two isomers ( $p$ - and $o$ - $n$-butyl derivatives) in a strict sense. The remarkable recovery of inhibitory potency of compound $\mathbf{1 3}$ may reflect such a strict recognition of the tail moiety by the enzyme.

Before it became widely recognized that natural acetogenins potently inhibit mitochondrial complex I, Sasaki et al. (25) indicated that hydroxylated bis-THF derivatives with different alkyl chains, which are structural components of natural acetogenins and resemble our $\Delta$ lac-acetogenins, form supramolecular complexes with $\mathrm{Ca}^{2+}$ at a ratio (ligand- $\mathrm{Ca}^{2+}$ ) of $4: 1$ or $2: 1$ in acetone and that the selectivity toward $\mathrm{Ca}^{2+}$ is superior to that of the carboxylic antibiotic A23187. On the basis of these observations, they suggested that biological activities of natural acetogenins might be related to the $\mathrm{Ca}^{2+}$ binding ability in biological membrane (25). To examine whether the inhibition of complex I activity by $\Delta$ lacacetogenins is related to $\mathrm{Ca}^{2+}$-binding ability, we carried out inhibition assays in the presence of various concentrations of $\mathrm{Ca}^{2+}$. The inhibition was not affected at all by $\mathrm{Ca}^{2+}$ in the reaction medium, indicating that the inhibitory action of $\Delta$ lac-acetogenins in mitochondrial membrane has no connection with the $\mathrm{Ca}^{2+}$-binding ability of the hydroxylated bis-THF skeleton.

Some biochemical studies have shown that tightly bound phospholipids are essential for the activity of several respiratory enzymes in the inner mitochondrial membrane. For instance, the presence of bound cardiolipin is essential for full activity of the ADP/ATP carrier (26), cytochrome $c$ oxidase $(27)$, and the cytochrome $b c_{1}$ complex $(28,29)$. The high-resolution structures of bound cardiolipin(s) have been described for the cytochrome $b c_{1}$ complex (30). The presence of an important bound phospholipid has not been noted for complex I, but it is also true that there is no experimental evidence to exclude this possibility. It may be noteworthy that NMR studies suggested that when natural acetogenins partition into liposomal membrane made from dimyristoylphosphatidylcholine (DMPC), the hydroxylated THF ring moiety interacts with the glycerol backbone and the polar headgroup region of DMPC (31). Since our $\Delta$ lac-acetogenins, which have hydrogen bond donating and accepting abilities in their hydrophilic portion, are typical amphiphilic molecules resembling phospholipids or detergents, it was interesting to investigate the possibility that they specifically bind to some unknown bound lipid which could be functionally important for complex I activity. We therefore examined whether $\Delta$ lac-acetogenins bind specifically to some specific lipids using a newly synthesized biotinylated $\Delta$ lac-acetogenin (compound 14) and various lipids (phosphatidylethanolamine, phosphatidylserine, phosphatidylinositol, phosphatidylcholine, phosphatidylglycerol, sphingomyelin, and cardiolipin) by ELISA measurement as described in the Experimental Procedures. Although the data are not shown, the measurement of the binding of biotinylated $\Delta$ lac-acetogenin to the lipids showed that the inhibitor has no ability to bind specifically to a certain lipid. It is therefore unlikely that $\Delta$ lac-acetogenins elicit inhibition primarily by interacting tightly to bound phospholipid. To identify the binding site of $\Delta$ lac-acetogenins, a photoaffinity-labeling study is necessary. The synthesis of photolabile $\Delta$ lac-acetogenin is currently underway in our laboratory.

\section{REFERENCES}

1. Zeng, L., Ye, Q., Oberlies, N. H., Shi, G., Gu, Z. M., He, K., and McLaughlin, J. L. (1996) Recent advances in annonaceous acetogenins, Nat. Prod. Rep. 13, 275-306.

2. Carmen Zafra-Polo, M., Carmen Gonzalez, M., Estornell, E., Sahpaz, S., and Cortes, D. (1996) Acetogenins from Annonaceae, inhibitors of mitochondrial complex I, Phytochemistry 42, 253271.

3. Alali, F. Q., Liu, X. X., and McLaughlin, J. L. (1999) Annonaceous acetogenins: recent progress, J. Nat. Prod. 62, 504-540.

4. Degli Esposti, M., Ghelli, A., Ratta, M., Cortes, D., and Estornell, E. (1994) Natural substances (acetogenins) from the family Annonaceae are powerful inhibitors of mitochondrial NADH dehydrogenase (complex I), Biochem. J. 301, 161-167.

5. Friedrich, T., Van Heek, P., Leif, H., Ohnishi, T., Forche, E., Kunze, B., Jansen, R., Trowitzsch-Kienast, W., Höfle, G., Reichenbach, H., and Weiss, H. (1994) Two binding sites of inhibitors in NADH:ubiquinone oxidoreductase (complex I), Eur. J. Biochem. 219, 691-698.

6. Okun, J. G., Lümmen, P., and Brandt, U. (1999) Three classes of inhibitor share a common binding domain in mitochondrial complex I (NADH-ubiquinone oxidoreductase), J. Biol. Chem. 274, 2625-2630.

7. Miyoshi, H. (2001) Probing the ubiquinone reduction site in bovine mitochondrial complex I using a series of synthetic ubiquinones and inhibitors, J. Bioenerg. Biomembr. 33, 223-231.

8. Hamada, T., Ichimaru, N., Abe, M., Fujita, D., Kenmochi, A., Nishioka, T., Zwicker, K., Brandt, U., and Miyoshi, H. (2004) Synthesis and inhibitory action of novel acetogenin mimics with bovine heart mitochondrial complex I, Biochemistry 43, 36513658.

9. Miyoshi, H., Ohshima, M., Shimada, H., Akagi, T., Iwamura, H., and McLaughlin, J. L. (1998) Essential structural factors of Annonaceous acetogenins as potent inhibitors of mitochondrial complex I, Biochim. Biophys. Acta 1365, 443-452.

10. Motoyama, T., Yabunaka, H., and Miyoshi, H. (2002) Essential structural factors of acetogenins, potent inhibitors of mitochondrial complex I, Bioorg. Med. Chem. Lett. 12, 2089-2092.

11. Abe, M., Kenmochi, A., Ichimaru, N., Hamada, T., Nishioka, T., and Miyoshi, H. (2004) Essential structural features of acetogenins: role of hydroxy groups adjacent to the bis-THF rings, Bioorg. Med. Chem. Lett. 14, 779-782.

12. Makabe, H., Miyawaki, A., Takahashi, R., Hattori, Y., Konno, H., Abe, M., and Miyoshi, H. (2004) Synthesis of two possible diastereomers of reticulatain-1, Tetrahedron Lett. 45, 973-977.

13. Makabe, H., Hattori, Y., Kimura, Y., Konno, H., Abe, M., Miyoshi, H., Tanaka, A., and Oritani, T. (2004) Total synthesis of cis-solamin and its inhibitory action with bovine heart mitochondrial complex I, Tetrahedron 60, 10651-10657.

14. Matsuno-Yagi, A., and Hatefi, Y. (1985) Studies on the mechanism of oxidative phosphorylation, J. Biol. Chem. 260, 14424-14427.

15. Ino, T., Nishioka, T., and Miyoshi, H. (2003) Characterization of inhibitor binding sites of mitochondrial complex I using fluorescent inhibitor, Biochim. Biophys. Acta 1605, 15-20.

16. Boveris, A. (1984) Determination of the production of superoxide radicals and hydrogen peroxide in mitochondria, Methods Enzymol. 105, 429-435.

17. Makino, A., Baba, T., Fujimoto, K., Iwamoto, K., Yano, Y., Terada, N., Ohno, S., Sato, S. B., Ohta, A., Umeda, M., Matsuzaki, K., and Kobayashi, T. (2003) Cinnamycin (Ro 09-0198) promotes cell binding and toxicity by inducing transbilayer lipids movement, J. Biol. Chem. 278, 3204-3209.

18. Majander, A., Finel, M., and Wikström, M. (1994) Diphenyleneiodonium inhibits reduction of iron-sulfur clusters in the mitochondrial NADH-ubiquinone oxidoreductase (complex I), J. Biol. Chem. 269, 21037-12042. 
19. Nakamaru-Ogiso, E., Sakamoto, K., Matsuno-Yagi, A., Miyoshi, H., and Yagi, T. (2003) The ND5 subunit was labeled by a photoaffinity analogue of fenpyroximate in bovine mitochondrial complex I, Biochemistry 42, 746-754.

20. Schuler, F., Yano, T., Bernardo, S. D., Yagi, T., Yankovskaya, V., Singer, T. P., and Casida, J. E. (1999) NADH-quinone oxidoreductase: PSST subunit couples electron transfer from iron-sulfur cluster N2 to quinone, Proc. Natl. Acad. Sci. U.S.A. 96, 4149-4153.

21. Yagi, T., and Matsuno-Yagi, A. (2003) The proton-translocating NADH-quinone oxidoreductase in the respiratory chain: the secret unlocked, Biochemistry 42, 2266-2274.

22. Lambert, A. J., and Brand, M. D. (2004) Inhibitors of the quinonebinding site allow rapid superoxide production from mitochondrial NADH-ubiquinone oxidoreductase (complex I), J. Biol. Chem. 279, 39414-39420.

23. Diamond, J. M., and Katz, I. Y. (1974) Interpretation of nonelectrolyte partition coefficients between dimyristoyl lecithin and water, J. Membr. Biol. 17, 121-154.

24. Miyoshi, H., Maeda, H., Tokutake, N., and Fujita, T. (1987) Quantitative analysis of partition behavior of substituted phenols from aqueous phase into liposomes made of lecithin and various lipids, Bull. Chem. Soc. Jpn. 60, 4357-4362.

25. Sasaki, S., Naito, H., Maruta, K., Kawahara, E., and Maeda, M. (1994) Novel calcium ionophore: supramolecular complexation by the hydroxylated-bistetrahydrofuran skeleton of potent anti- tumor annonaceous acetogenins, Tetrahedron Lett. 35, 33373340.

26. Beyer, K., and Nuscher, B. (1996) Specific cardiolipin binding interferes with labeling of sulfhydryl residues in the adenosine diphosphate/adenosine triphosphate carrier protein from beef heart mitochondria, Biochemistry 35, 15784-15790.

27. Robinson, N. C., Zborowski, J., and Talbert, L. H. (1990) Cardiolipin-depleted bovine heart cytochrome $c$ oxidase: binding stoichiometry and affinity for cardiolipin derivatives, Biochemistry $29,8962-8969$.

28. Gomez, B., Jr., and Robinson, N. C. (1999) Phospholipase digestion of bound cardiolipin reversibly inactivates bovine cytochrome $b c_{1}$, Biochemistry 38, 9031-9038.

29. Schägger, H., Hagen, T., Roth, B., Brandt, U., and von Jagow, G. (1990) Phospholipid specificity of bovine heart $b c_{1}$ complex, Eur. J. Biochem. 190, 123-130.

30. Lange, C., Nett, J. H., Trumpower, B. L., and Hunte, C. (2001) Specific roles of protein-phospholipid interactions in the yeast cytochrome $b c_{1}$ complex structure, EMBO J. 20, 6591-6600.

31. Shimada, H., Grutzner, J. B., Kozlowski, J. F., and McLaughlin, J. L. (1998) Membrane conformations and their relation to cytotoxicity of asimicin and its analogues, Biochemistry 37, 854-866.

BI0479003 